\title{
Utilization WhatsApp Group in Long Distance Study to Increase Class Student Discipline V Elementary School
}

\author{
Mukhasin $^{1}$, Ana Andriani ${ }^{2}$ \\ $\left\{\underline{\text { mukhasin83@gmail.com }}{ }^{1}, \underline{\text { ana.andriani@gmail.com }}{ }^{2}\right\}$ \\ ${ }^{1,2}$ Universitas Muhammadiyah Purwokerto
}

\begin{abstract}
The low attitude discipline student at the time of long distance study that cause comprehension under communication towards lesson matter is background in this watchfulness. Aim from this watchfulness detects utilization WhatsApp group in study daring towards attitude enhanced discipline class student V elementary school. Watchfulness kind that used literature study watchfulness. Data collecting method that used in this watchfulness documentation method. Contents analysis (content analysis) be data analysis technique that used in this watchfulness. Data analysis is done to pass process chooses, compare, unite and separate various explanation up to found relevant. Based on literature watchfulness result from several journals that written by previous researcher has demoed that utilization WhatsApp group in study daring very useful in course of increase student discipline.
\end{abstract}

Keywords: attitude discipline, long distance study, elementary school

\section{Introduction}

Education is one of the investment in human resource development with as tool increases ability and ability in cross life. Education aim should education pressure not only in cognate aspect or ability thinks, but also must give top priority character, refine conscience, so that can develop cognizance about ability and not entrant ability educates [1]. Physical education and spiritual must walk according to balance to get education result maximal that is student that has good character.

Character education for entrant educates elementary school very need especially character discipline. Character that has by somebody basically formed pass study process enough long. Human character not something that brought from the day of born. More than that, character is form or even also environment forging and also person - one who in around environment. Character is formed to pass study process at several places, homey, school, and at environment around residence [2]. Character education delivery must enforceable good in direct study also in long distance study. Troubleshoot the fact often appear at the (time) of study entrant discipline problem educates. Discipline an attitude that make somebody can to obey a task or job that felted as according to self-responsibility and as according to moral values. Entrant will educate that has attitude discipline will can to will obey every regulation [3]. Attitude discipline that has entrant educates must applicable good in school environment, also society.

Discipline individual behavior that can bidding value with norm that trusted by society or a group. When related with this watchfulness context so that attitude discipline be condition or where does student can to obey regulations operative in class [4]. Indicator discipline learn to 
be four that is: a) loyalty towards school discipline, b) loyalty towards study activity at school, c) carry out duties that be to account to answer it, and d) discipline learn at home [5].

Entrant educates / student one of [the] factor importunes in the world of education and to walk it teaching and learning system. Student one who come to school to get or study several education types [6]. But practically entrant educates not yet thoroughly has discipline in learn. Several phenomena not discipline entrant educates that is: late come to school, not discipline in uniformed, less detect manner learns good that is learn moment approach test, lazy in do duties that given by teacher, less can learn self, cannot divide time to learn, still compulsion existence to learn from teacher, often cheat in class the friend job result, and do homework task moment follow other subject that causes process learns to be disturbed.

The low entrant discipline educates at the (time) of study is influenced by several things among others: 1) condition pandemic that is bumping into Indonesia country and world in general cause movement space restriction for student, 2) study method less variety, 3) addition task too much, 4) study that done according to daring or where a large part education executants belong teacher and student not yet ready for face condition.

Science progress and technology very influential towards education world development. Change that according to significant from study directly be long distance study many change educators patterned thinking is modern in develop study. Long distance study or called (PJJ) to be study that done without meet between student and teacher. Study daring study that can to confront teacher and student in carry out study interaction constructively internet [7]. Study daring be internet network utilization in course of study. With long distance study / daring good student, also has time freedom of action in the execution. As to platform that can be used in this long distance study is among others: google classroom, goggle meet, zoom, WhatsApp group and others [8].

The fifth grade of elementary school a large part carries out long distance study. One of [the] long distance study media familiar and often used that is media WhatsApp. Social media WhatsApp (WA) be one of [the] communication media in this time many liked by all walks of life. Social media use WhatsApp this be one of [the] social media that include overall society importance in communicating to fulfil need each [9]. But in course of long distance study necessary attention existence either from also from teacher.

\section{Method}

Watchfulness method that used in watchfulness literature study from various journal and book. Literature study method is series that activity with book data collecting method, read and register, with cultivate watchfulness ingredient that based on from journals or article that canvass to hit troubleshoot related to problem that want to solved. In watchfulness, found several differences in watchfulness result [10]. Literature study or also mean data collecting technique with do observation towards book, literature, note, with various report related to problem that want to solved [11].

data that used in this watchfulness secondary data. secondary data that is taken from watchfulness that done by earlier researcher, not from observer directly. data collecting method that used in this watchfulness documentation method. documentation method is systematic data collecting procedure to reviews good document prints also electronic [12]. data analysis technique that used in this watchfulness contents analysis method (content analysis). this analysis is used to get inferences valid and can be canvassed to repeat based on the context. in this analysis be done process will choose, compare, unite and separate various explanation up to found relevant [13]. 


\section{Result and Discussion}

Literature study awareness is a watchfulness method that collects data from various sources that has been done by previous researchers. Based on the information gathered, one of the fitur whatsapp groups can be used as a study tool daring whatsapp group. This media can be created based on a school subject. Whatsapp group is a space for online learning, where teachers and permanent students can follow the progress of their studies [13]. Whatsapp study group is an effective tool for the study process with various student condition situation factors. Whatsapp groups are a simple media to use, but there are no time constraints, making them very influential in terms of discipline and student responsibility. [14].

Utilization that carried out by class teacher in study activity uses media WhatsApp group hold opener activity, kernel, and casing. Then fitur often used fitur photo, video, document, WhatsApp group, and call (telephone) directly. Ease is felled with presence fitur WhatsApp and also its use easy and can be used by various circle [15].

WhatsApp group is chosen as one of [the] study media, because reviewed from total side user, function and manner its use, where can educator can share (sharing) lesson matter or task in the form of picture, pdf, ppt, doc, xls, audio, video according to direct and ask conception (answer) from group entrant (entrant educate) s. WhatsApp also be application good to study based on clever hand phone, like to finish duties from educator. Related to cellular application task completion likes WhatsApp this more liked than discussion at class. Because pass group, whatever that sent by educator or entrant will educate direct can be accessioned by entrant group that online. Mean, study activity uses group application WhatsApp bring benefit for accomplishment and entrant attitude educates towards study and education according to mobile [16].

WhatsApp group this give many surplus, that is: a) not extravagant quota likes other application. b) make easy study during pandemic covid-19. c) pass WhatsApp group, matter that submitted teacher can at access by entire students. d) can do discussion about matter subject [13]. e) study can be accessioned easily that is pass smartphone or ware other and studying time flexible can be done with chance any time, f) vast insight with conventional method caused by uses various access many and given to chance loads of time in accessing knowledge [14].

Besides several surplus that mentioned, there are some deficit that is: a) weak internet network is obstacle in downloaded the lesson that submitted by the teacher. B) message quantity enters, cause slow hand phone. C) when does individual evaluation test sent to pass group, student unfinished can see working result the other friends [13]. D) difficult to controls serious student follows lesson and not, e) study more many theoretical compared with practice [14].

Solution that taken to overcome the mentioned a) teacher maximizes to use existing media that is with voice note in WhatsApp and give handout so that entrant educate can study matter self-supporting, b) teacher uses study media that to interesting to ask student in learn, c) teacher can apply maximal little group study 3 person, so that student can mutual share erudition, d) teacher can give direct directive to student pass WhatsApp individual when there there is a problem in study [14].

\section{Conclusion}

Based on book study and literature study watchfulness result and watchfulness that carried out by previous researcher inferential that utilization WhatsApp group in long distance study very help and make easy study in create attitude discipline. Media WhatsApp prepare various application to make easy student in carry out study process so that can help student in increase discipline in course of study. Surplus uses WhatsApp group in study cheap cost, easy accessioned, time more flexible, with easily used. There various means to overcome obstacle in 
this media use among others teacher maximizes application existing, form little group, and give directive directly. Researcher hope this watchfulness can useful alternatively study for reader and researcher furthermore that social media use in course of study.

\section{REFERENCES}

[1] Suyatno. Teknik Pembelajaran Bahasa dan Sastra. Surabaya: SIC. 2004.

[2] Andriani A, Wakhudin W. Implementasi Pendidikan Karakter Melalui Model Pembelajaran Discovery Learning Di Mim Pasir Lor Karanglewas Banyumas. Jurnal Pengabdian Masyarakat. 2020 Nov 3;1(2):51-63.

[3] Jauhary H. Hidup sukses dengan disiplin. Semarang, Indonesia: MutiaraAksara. 2019.

[4] Pancarani DP. Peran guru dalam membentuk sikap disiplin siswa kelas I Sekolah Dasar melalui penghargaan dan konsekuensi (Doctoral dissertation, Universitas Pelita Harapan).

[5] Daryanto. Strategi dan Tahap Mengajar. Bandung: CV YramaWidya. 2013.

[6] Safitri C. Hubungan Antara Dukungan Sosial dengan Motivasi Berprestasi pada Siswa Kelas XI Madrasah Aliyah Al Wasliyah 12 Perbaungan (Doctoral dissertation, Universitas Medan Area).

[7] Kuntarto E. Keefektifan model pembelajaran daring dalam perkuliahan bahasa Indonesia di perguruan tinggi. Journal Indonesian Language Education and Literature. 2017 Dec;3(1).

[8] Magdalena I, Mauludyana BG, Gusmawati L. Efektivitas Pembelajaran Daring Menggunakan Media Online Selama Pandemi Covid-19 di SDN Curug Kulon 1. BINTANG. 2020 Aug 31;2(2):326-35.

[9] Yensy NA. Efektifitas pembelajaran statistika matematika melalui media whatsapp group ditinjau dari hasil belajar mahasiswa (masa pandemik Covid 19). Jurnal Pendidikan Matematika Raflesia. 2020 Jun 11;5(2):65-74. 